\title{
A Study on Biochemical Constituents and Anti-Bacterial Activity of Bark of Polyalthia longifolia
}

\author{
M. Selvarani ${ }^{1}$, P. Balaji ${ }^{2 *}$ and G. Soundarya ${ }^{2}$ \\ ${ }^{1}$ Forest College and Research Institute, Mettupalayam, India \\ ${ }^{2}$ Department of ARM, TNAU, Coimbatore- 641 003, India
}

*Corresponding author

\section{A B S T R A C T}

Keywords

Polyalthia

longifolia, methanol extract- GC-MS

Article Info

Accepted:

xx August 2019

Available Online:

xx September 2019
Polyalthia longifolia is a tall evergreen tree belongs to the family Annonaceae. The present study includes the detailed exploration of biochemical constituents and anti-microbial activities of bark of Polyalthia longifolia. To study the biochemical and antibacterial activity, the Methanol extract of powdered bark of Polyalthia longifolia was prepared by using Soxhlet apparatus. Then the extract studied in GC-MS to know the biochemical. GC-MS results were revealed the presence of Cycloheximide, Cholestrol, Fluorescein o-acrylate, 11 Cis-Retinal, Cetyl alcohol, Tridecyltrichloroacetate, Thymol, Methyl palmitate, Cyclandelate, Dibutyl phthalate, Methyl stearate, Enoxolone or glycyrrhetinic acid. Presence of these compounds shows the properties of anti-diabetic, polymer processing, additives, anti-foam, effective in the treatment of peptic ulcer, production of detergents, soaps and cosmetics such as shampoos and shaving cream products.

\section{Introduction}

Polyalthia longifolia found in tropic and tropic regions upto $1500 \mathrm{~m}$. This is native to India and Srilanka (1). A tall evergreen, handsome, pyramid like columnar tree; main stem straight, undivided, growing upto $12 \mathrm{~m}$ or more. Branches slender, short about 1-2m long, glabarous and pendulous. The longest branch is seen at the base and shortest at the end of the trunk, giving an appearance of conical crown (2). Leaves are long, alternate, enstipulate, distichour, mildly aromatic, 7.5$23 \mathrm{~cm}$ long, $1.5-3.8 \mathrm{~cm}$ width, shining, glabrous,narrowly lanceolat, tapering to a fine acuminate apex, margin markedly undulate, pinnately veined, lathered of subcoriaceous, shortly petiolate; petiole about $6 \mathrm{~mm}$ long. Flowers arise from branches below the leaves nonfragrant, $2.5-3.5 \mathrm{~cm}$ across yellowish to green, in fasciles or shortly pendunculate umbels; petals 6,2 seriate, flat, from a broad 
base lanceolate, long accumulate, spreading and sepals 3, broad, short, triangular, the tips reflexed. Stamens many, coneate; connective truncately dilated beyond the cells(3).

Ovaries indefinites; ovules 1-2; style oblong. Ripe fruits ovoid, $1.8-2 \mathrm{~cm}$ long, numerous, stalked, glabrous, 1 seeded; stalk $1.3 \mathrm{~cm}$ long, short glabrous. Seeds smooth, shining. Flowering fruiting during February- June (4). It is generally propagated through seeds, but occasionally through soft wood cutting and air layering. Bark of polyalthia longifolia light green in colour while drying it exhibit bitter odour. Bark of this tree has significant medicinal properties Ayurveda. Bark of this tree having Javaranashaka (reducing fever) action. Bark is useful in fever. The bark is bitter, acrid, cooling, febrifuge and anthelmintic. It is useful in fever, skin disease, diabetes, hypertension, helminthiasis, and vitiated conditions of vata and pitta.(5)

\section{Materials and Methods}

A well grown, healthy, plus tree was selected for bark collection from Forest College and Research Institute, Mettupalayam, Coimbatore, Tamilnadu. Bark of Polyalthia longifolia was collected.

\section{Solvent extraction}

The tree bark collected were washed under tap water and dried under shade for about two weeks. Then the dried one was powdered using mechanical grinder (6).

Powdered bark of Polyalthia longifolia (5 grams) was taken into the Soxhlet extractor. $25 \mathrm{ml}$ of extraction solvent (Methanol) was taken in to the round bottomed flask and was placed on the mantle, temperature was set at $55^{\circ} \mathrm{C}$. The extraction was continued for 1 hour. Finally the extract collected in the round bottom flask was concentrated and kept under cold condition for preventing further evaporation of the extract. Then the extract was given for GC-MS to find out the constituents.

GC-MS studies: principle of gas chromatography -mass spectrometry

Gas Chromatography is used to separate volatile compounds in a mixture. The extracted solvent was analysed for its bio chemical constituents through Gas Chromatography Mass Spectrometer (GCMS). The GC-MS analysis was carried out using a Thermo GC - Trace Ultra ver: 5.0, Thermo MS DSQ II with $30 \mathrm{~m} \times 0.25 \mathrm{~mm} \times 0.25 \mu \mathrm{m}$ of capillary standard non-popular column.

The instrument was set to an initial temperature of $70^{\circ} \mathrm{C}$, and maintained at this temperature for $3 \mathrm{~min}$. At the end of this period the oven temperature was rose up to $260^{\circ} \mathrm{C}$, at the rate of an increase of $6^{\circ} \mathrm{C} / \mathrm{min}$, and maintained for $2 \mathrm{~min}$.

Injection port temperature was ensured at $250^{\circ} \mathrm{C}$ and Helium flow rate at $1.0 \mathrm{ml} / \mathrm{min}$. The ionization voltage was $70 \mathrm{eV}$. The samples were injected in split mode as 10:1. Mass spectral scan range was set at $40-700(\mathrm{~m} / \mathrm{z})$.

The ion source temperature was maintained at $220^{\circ} \mathrm{C}$ and Interface temperature was at $240^{\circ} \mathrm{C}$. The MS start time was $0.00 \mathrm{~min}$, and end time was $40.51 \mathrm{~min}$. Interpretation on mass spectrum of GC-MS was done using the database of the South India Textile Research Association (SITRA).

The mass spectrum of the unknown component was compared with the spectrum of the known components stored in the SITRA library. The name, molecular weight and structure of the components of the test materials were confirmed. 


\section{Results and Discussion}

The results of GC-MS shows the presence of Cycloheximide, Cholestrol, Fluorescein oacrylate, 11 Cis-Retinal, Cetyl alcohol, Tridecyl trichloroacetate, Thymol, Methyl palmitate, Cyclandelate, Dibutyl phthalate, Methyl stearate, Enoxolone or glycyrrhetinic acid.

Cycloheximide have the properties of antidiabetic and anti-dione.

Cholesterol is a precursor molecule for several biochemical pathways and synthesis of vitamin $\mathrm{D}$ and all steroid hormones, including the adrenalgland hormones cortisol and aldost erone, as well as the sex hormones progesterone, estrogens, and testosterone, and their derivatives.

11-cis Retinal is an isomer of retinal. The 11cis Retinal forms half of the rhodopsin (type of visual pigment) molecule (the other half of rhodopsin is composed of opsin) which is an essential endogenous chemical for the function of visual perception.

Cetyl alcohol is used in metal working fluids/rolling oils, cleaning agents, road and construction applications (binders and release agents), polymer processing (plastics and rubbers) and mining chemicals.

Thymol has antimicrobial activity because of its phenolic structure, and has shown antibacterial activity against bacterial strains including Aeromonas hydrophila and Staphylococcus aureus. It is also used as a preservative in halothane, an anaesthetic, and as an antiseptic in mouthwash. Thymol is also used as a rapidly degrading, non- persisting pesticide. Methyl palmitate is Used as solvent in perfume materials and used in flea and tick products for pets. And also used as pesticide free treatment against head lice which works by dissolving the wax that covers the exoskeleton of head lice, killing them by dehydration.

Pristanic acid or Isopropyl palmitate can be Used in production of detergents, soaps and cosmetics such as shampoos and shaving cream products. And also used as a negative plate additive in the manufacture of lead-acid batteries.

Enoxolone or glycyrrhetinic acid is used as used in flavoring and it masks the bitter taste of drugs like aloe and quinine. It is effective in the treatment of peptic ulcer and also has expectorant properties. Dibutyl phthalate is used as Polymers, paints, ink, additives, antifoam and ecto-parasiticide.

The result of GC-MS analysis revealed that the following eleven constituents are having the peak point at different retention time.

The identified constituents are Cycloheximide, Cholestrol, Fluorescein o-acrylate, 11 CisRetinal, Cetyl alcohol, Tridecyl trichloroacetate, Thymol, Methyl palmitate, Cyclandelate, Dibutyl phthalate, Methyl stearate, Enoxolone or glycyrrhetinic acid. These compounds are found to possess the properties of anticancers, anti-inflammatory, antidepressant and these compounds places their application in soaps, perfumes, inks, polymers and pesticides. From the investigation of antibacterial activity of bark extract of Polyalthia longifolia, the positive result was obtained by the presence of inhibition zone in the petri plates around the filter paper loaded with the bark extract. 
Table.1 Biochemical compounds in the bark extract

\begin{tabular}{|c|c|c|c|c|c|c|}
\hline $\begin{array}{l}\text { S. } \\
\text { n } \\
\text { o }\end{array}$ & Compound name & $\begin{array}{l}\text { Molecula } \\
\mathbf{r} \\
\text { formulae }\end{array}$ & Common name & $\begin{array}{l}\text { Retention } \\
\text { time }\end{array}$ & $\begin{array}{l}\text { Molecula } \\
\text { r } \\
\text { Weight }\end{array}$ & Uses \\
\hline 1 & $\begin{array}{l}\text { 5-tert-butyl-2-methyl-4-(4- } \\
\text { morpholinylmethyl)-3- } \\
\text { furoic acid }\end{array}$ & $\mathrm{C}_{4} \mathrm{H}_{23} \mathrm{NO}$ & Cycloheximide & 3.07 & 281 & $\begin{array}{l}\text { Anti-diabetic } \\
\text { anti-dione }\end{array}$ \\
\hline 2 & $\begin{array}{l}\text { Cholest-2-en-19-ol, (5à)- } \\
\text { (CAS) }\end{array}$ & $\mathrm{C}_{27} \mathrm{H}_{46} \mathrm{O}$ & Cholestrol & 5.34 & 386 & $\begin{array}{l}\text { synthesis } \\
\text { vitamin D }\end{array}$ \\
\hline 3 & Oxo - eicosa - hexa - diene & $\mathrm{C}_{20} \mathrm{H}_{28} \mathrm{O}$ & 11 Cis-Retinal & 8.27 & 284 & visual perception \\
\hline 4 & 1-Hexadecanol (CAS) & $\mathrm{C}_{16} \mathrm{H}_{34} \mathrm{O}$ & Cetyl alcohol & 13.42 & 242 & $\begin{array}{l}\text { metal working } \\
\text { fluids }\end{array}$ \\
\hline 5 & $\begin{array}{l}\text { Phenol, 5-methyl-2-(1- } \\
\text { methylethyl)- (CAS) }\end{array}$ & $\mathrm{C}_{10} \mathrm{H}_{14} \mathrm{O}$ & Thymol & 20.40 & 150 & $\begin{array}{l}\text { antimicrobial } \\
\text { activity }\end{array}$ \\
\hline 6 & $\begin{array}{l}\text { Hexadecanoic acid, methyl } \\
\text { ester (CAS) }\end{array}$ & $\mathrm{C}_{17} \mathrm{H}_{34} \mathrm{O}_{2}$ & $\begin{array}{l}\text { Methyl } \\
\text { palmitate }\end{array}$ & 21.73 & 270 & Pesticide \\
\hline 7 & $\begin{array}{l}\text { 1,2-Benzenedicarboxylic } \\
\text { acid, dibutyl ester (CAS) }\end{array}$ & $\mathrm{C}_{16} \mathrm{H}_{22} \mathrm{O}_{4}$ & $\begin{array}{l}\text { Dibutyl } \\
\text { phthalate }\end{array}$ & 24.98 & 278 & $\begin{array}{l}\text { Polymers,paints, } \\
\text { ink, additives, } \\
\text { anti-foam and } \\
\text { ecto-parasiticide }\end{array}$ \\
\hline 8 & $\begin{array}{l}\text { Octadecanoic acid, methyl } \\
\text { ester (CAS) }\end{array}$ & $\mathrm{C}_{19} \mathrm{H}_{38} \mathrm{O}_{2}$ & Methyl stearate & 25.53 & 298 & $\begin{array}{l}\text { production of } \\
\text { detergents, soaps } \\
\text { and cosmetics }\end{array}$ \\
\hline 9 & Holothurinogenin-4 & $\mathrm{C}_{30} \mathrm{H}_{4}{ }_{6} \mathrm{O}_{4}$ & $\begin{array}{l}\text { Enoxolone or } \\
\text { glycyrrhetinic } \\
\text { acid }\end{array}$ & 32.13 & 470 & $\begin{array}{l}\text { masks the bitter } \\
\text { taste of drugs }\end{array}$ \\
\hline
\end{tabular}

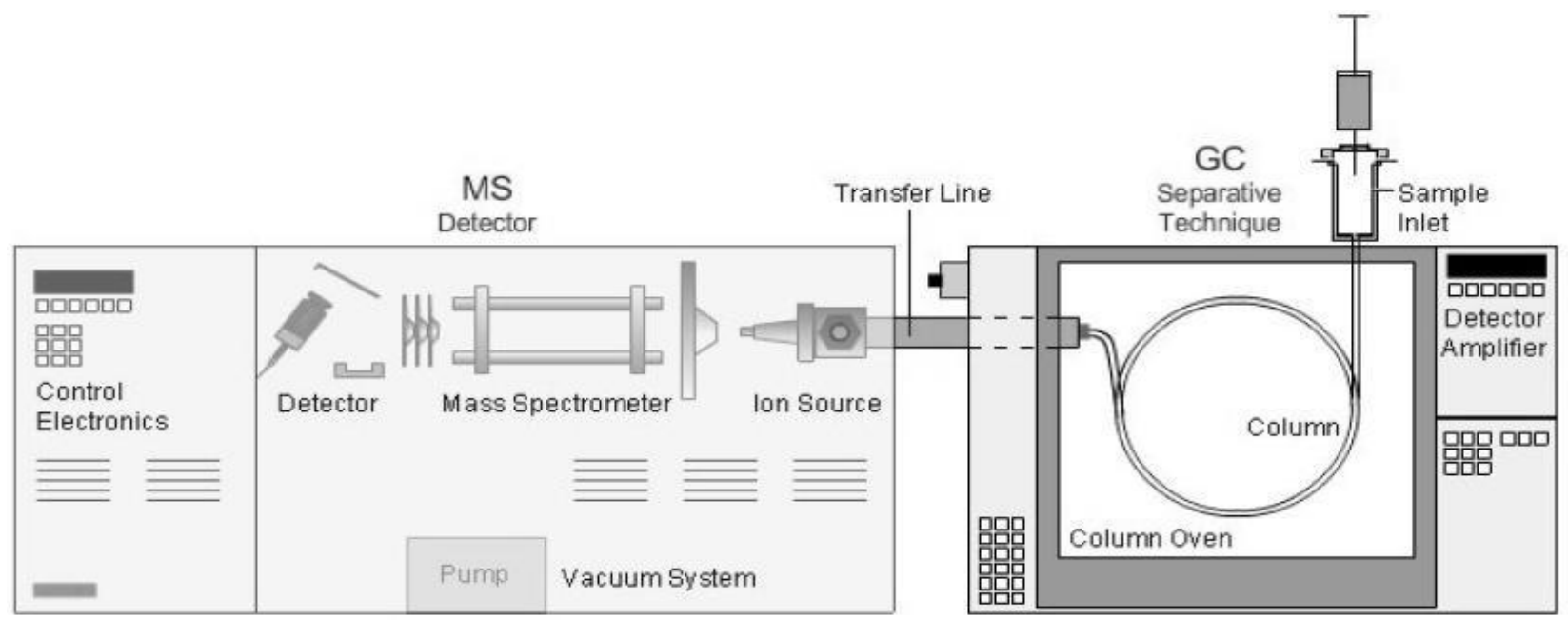




\section{CHOLESTROL}
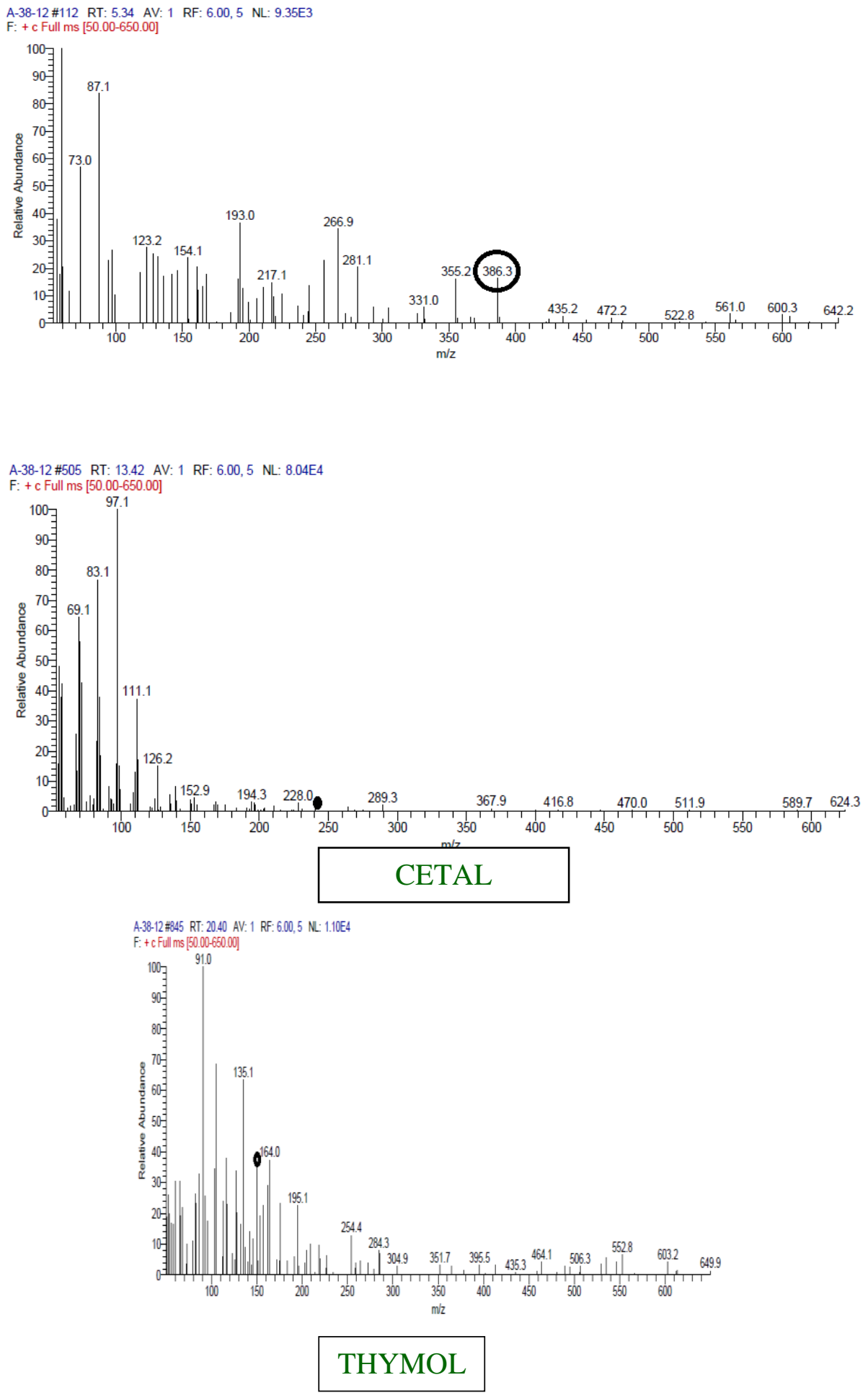


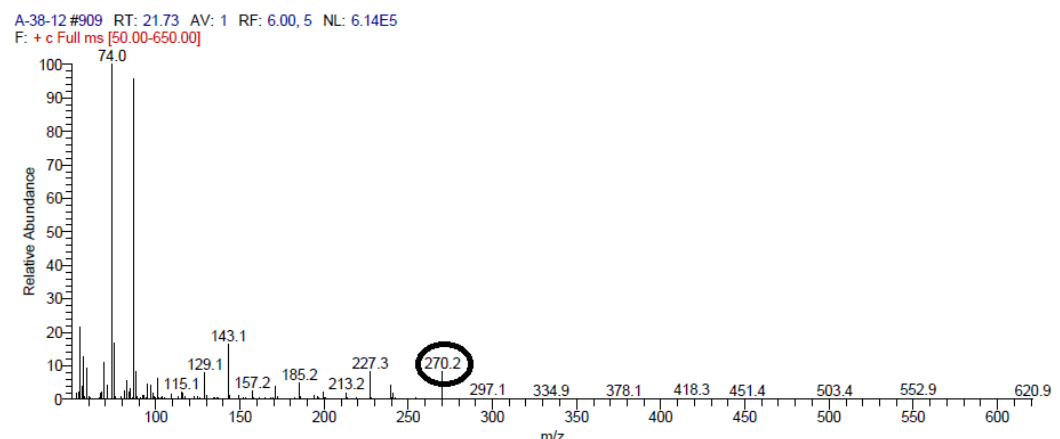

METHYL PALMITATE

A-38-12\#1060 RT: 24.98 AV: 1 RF: $6.00,5$ NL: $3.85 E 6$

F: + c Full ms [50.00-650.00]

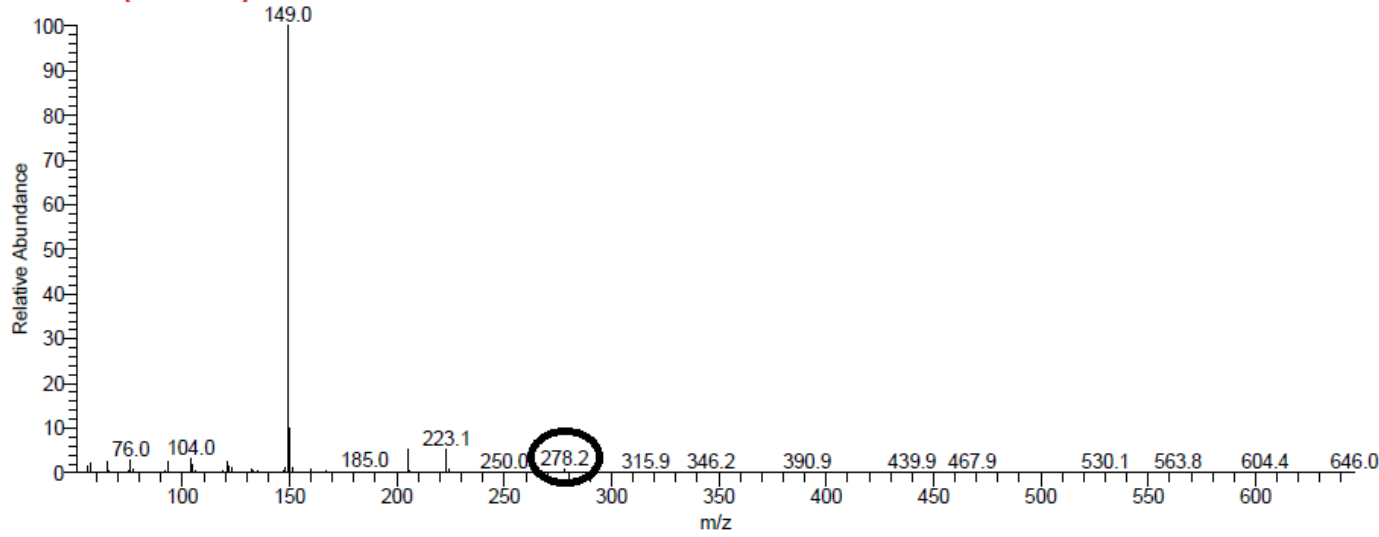

BUTYL PHTHALATE

A-38-12 \#1084 RT: 25.53 AV: 1 RF: $6.00,5$ NL: $1.65 E 5$ F: + c Full ms [50.00-650.00]

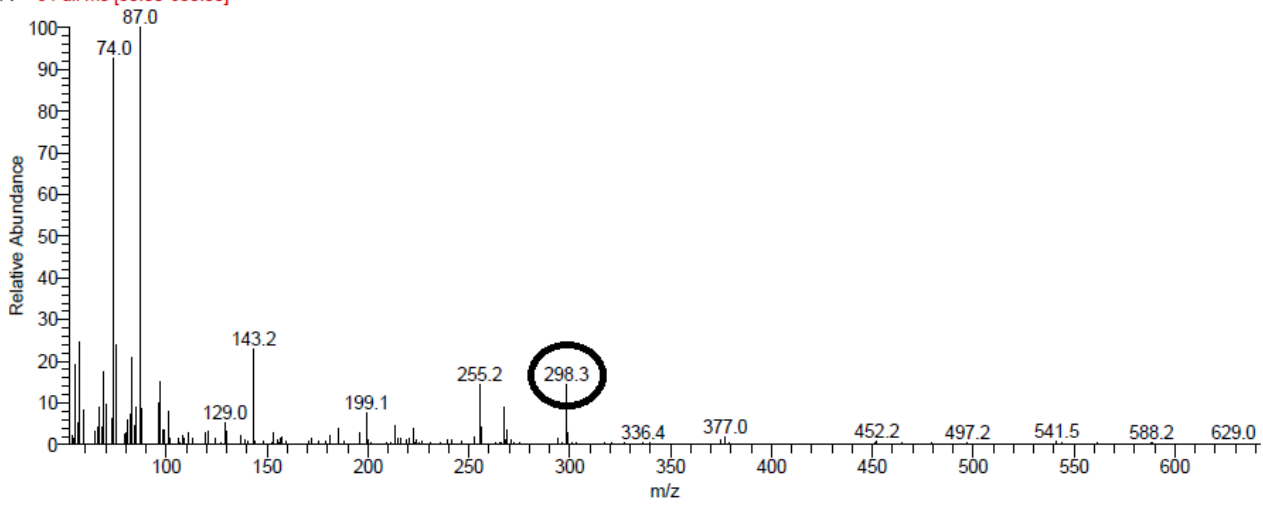




\section{METHYL STEARATE}

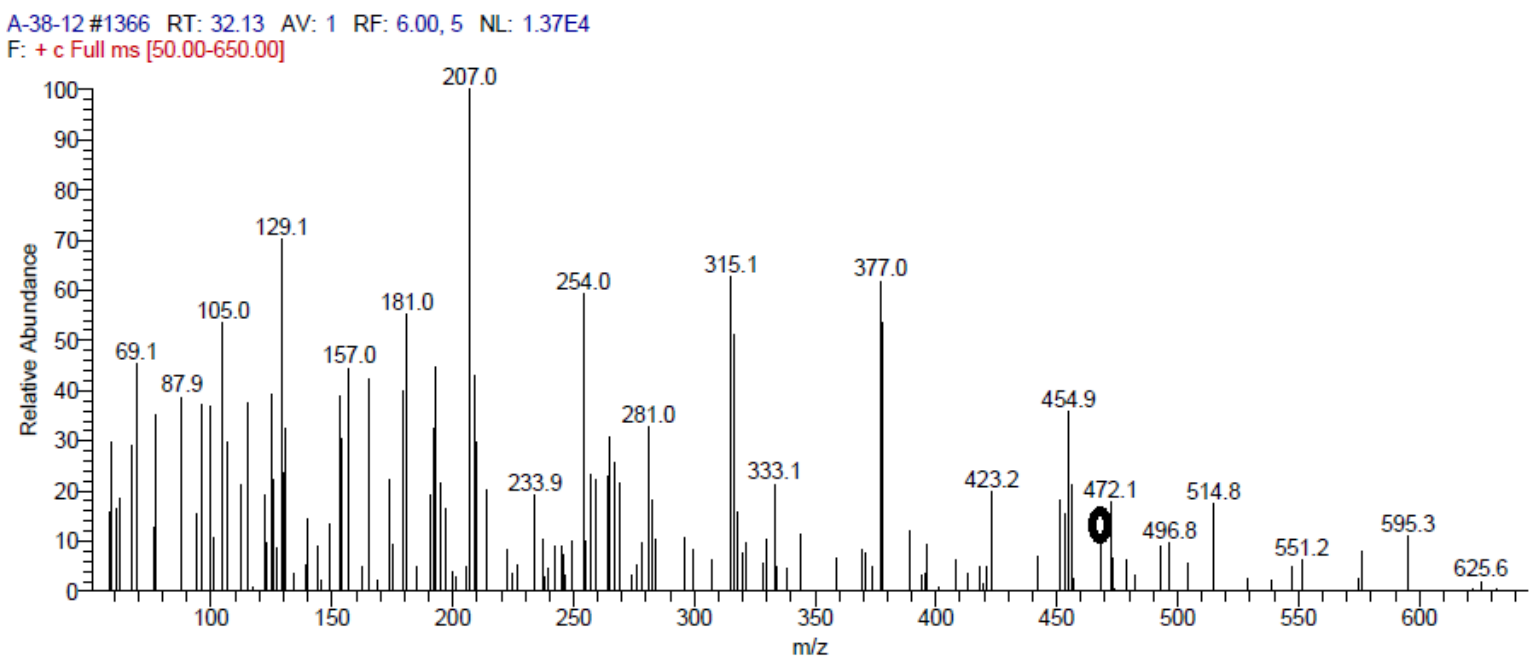

\section{References}

Anonymous.(1994) Ethnobotany in the search for new drugs. Ciba Foundation Symposium 188, John Wiley and Sons, New York, USA

Lemmens RHMJ, Bunyapraphatsara N.(2003). Plant Resources of South-East Asia No.12(3). In Medicinal and Poisonous plants 3,Backhuys Publishers: Leiden, Netherlands

Wu Y.C., Duth CY., Wang S.K., Chen K.S., Yang T.H.(1990) Two new natural azofluorene alkaloids from P.longifolia: Journal of Natural Products. 1990;5: 1327-1331.
Bose TK, Das P and Maiti GG. In Trees of the world, Bhubaneswar, India: Regional plant Resource center. 1998; 1:370.

Katkar KV, Suthar AC, and Chauhan VS. The Chemistry, Pharmachologic, and Therpeutic Applications of Polyalthialongifolia. Pharmachology. 1986; 38:627-629.

Goutam Ghosh et al., Anti-hyperglycemic and antioxidant activity of stem bark of polyalthia longifolia var. angustifolia, Scholars research library, ISSN 09755071.

Ghosh G, Subudhi BB, Banerjee M, Mishra SK. Ind J Chem. 2011; 50B: 15101512.

\section{How to cite this article:}

Selvarani, M., P. Balaji and Soundarya, G. 2019. A Study on Biochemical Constituents and Anti-Bacterial Activity of Bark of Polyalthia longifolia. Int.J.Curr.Microbiol.App.Sci. 8(09): 2492- 2498. doi: https://doi.org/10.20546/ijcmas.2019.809.289 